\title{
Cerebrospinal fluid proteins and free amino acids in patients with solvent induced chronic toxic encephalopathy and healthy controls
}

\author{
Bente Elisabeth Moen, K R Kyvik, B A Engelsen, T Riise
}

\begin{abstract}
The concentrations of protein, albumin, IgG, and free amino acids in the cerebrospinal fluid of 16 patients with chronic toxic encephalopathy due to organic solvents were measured. The patient group consisted of all patients with this diagnosis in a neurological department in 1985. The diagnosis was based on neuraesthenic symptoms, pathological psychometric performance, and verified exposure to neurotoxic organic solvents. A control group of 16 patients with myalgias or backache, or both, and no signs of disease was used for comparison. The purpose was to study possible changes in the cerebrospinal fluid that might contribute to understanding the aetiology of solvent induced chronic toxic encephalopathy. A rise in protein, albumin, and IgG was found in the patient group compared with the control group, as well as reduced concentrations of phosphoethanolamine, taurine, homocarnosine, ethanolamine, alpha-aminobutyric acid, and leucine. Using a stepwise multiple regression analysis, taurine was negatively correlated to exposure to solvents. These findings may indicate membrane alterations in the central nervous system related to exposure to organic solvents.
\end{abstract}

Case reports ${ }^{12}$ and epidemiological studies $^{3-5}$ of workers occupationally exposed to organic solvents suggest the existence of a chronic toxic encephalopathy. This diagnosis has been debated for some time but the syndrome is generally accepted by occupational toxicologists. The World Health Organisation and a working group in the United

University of Bergen, N-5021 Haukeland Sykehus, Norway

Department of Neurology

B E Moen, K R Kyvik

Department of Pathology

B A Engelsen

Section of Information and Statistics

T Riise
States have suggested classification systems for the syndrome. ${ }^{67}$

An increase of proteins and albumin ratio has been found in the cerebrospinal fluid of patients exposed to solvents. ${ }^{8}$ These findings may be related to aetiological mechanisms of the syndrome and the present study was made to examine this further. Amino acids and proteins in the cerebrospinal fluid were studied. Amino acids are precursors of several neurotransmitters and some of them may themselves act as neurotransmitters or modulators of neural activity. ${ }^{9}$ Some amino acids have been proposed as neuromodulators with behavioural relevance. ${ }^{910}$ This may be of importance concerning chronic toxic encephalopathy as behavioural changes are seen in these patients. No studies of amino acid concentrations in the cerebrospinal fluid of patients with chronic toxic encephalopathy due to organic solvents have previously been performed.

\section{Material and methods \\ PATIENTS}

At our department of neurology in 198519 patients were diagnosed as having chronic toxic encephalopathy. The diagnosis was made after an interview with the patient, a general and a neurological examination, neuromyographic measurements, electroencephalography, registration of visual and auditory evoked potentials, a computed cerebral tomogram, and an examination of the cerebrospinal fluid. Furthermore, the patients performed neuropsychological tests including tests of psychometric intelligence and memory (WAIS), tests of adaptive sensory and motor functions (Halstead-Reitan battery), and a personality test (MMPI). Age and educational level were considered when evaluating the results. In addition, the following blood analyses were performed; haematological examination, serum electrolyte study, liver function tests, serological test for syphilis, serum vitamin B12 level, thyroid function studies, serum triglyceride level, serum cholesterol level, serum immunoglobulin level, fasting serum glucose level, and a glucose tolerance test. Urine was examined for the presence of glucose, protein, and blood, and a microscopic study was performed. The diagnosis was based on the presence of neuraesthenic 
Table 1 Occupations and organic solvent exposure in 16 patients with chronic toxic encephalopathy

\begin{tabular}{lll}
\hline Occupation & $\begin{array}{l}\text { No of } \\
\text { patients }\end{array}$ & Exposure \\
\hline Painter/spraypainter & 6 & $\begin{array}{l}\text { Mixtures of } \\
\text { hydrocarbons, mostly } \\
\text { xylenes }\end{array}$ \\
Worker in paint industry & 5 & $\begin{array}{l}\text { Mixtures of } \\
\text { hydrocarbons, mostly } \\
\text { xylenes, n-hexane }\end{array}$ \\
Worker in plastic industry & 2 & $\begin{array}{l}\text { Mixtures of } \\
\text { hydrocarbons, mostly } \\
\text { styrene, acetone } \\
\text { Mixtures of } \\
\text { hydrocarbons, mostly } \\
\text { toluene, xylenes, } \\
\text { trichloroethylene } \\
\text { Mixtures of } \\
\text { hydrocarbons, mostly } \\
\text { trichloroethylene } \\
\text { Wixtures of } \\
\text { hydrocarbons, mostly } \\
\text { toluene, hexanes, styrene, } \\
\text { xylenes }\end{array}$ \\
\hline $\begin{array}{l}\text { Worker in mechanical } \\
\text { industry }\end{array}$ & 1 & 1 \\
$\begin{array}{l}\text { Able seaman on chemical } \\
\text { tanker }\end{array}$ & 1 &
\end{tabular}

symptoms and abnormal performance in psychometric tests preceded by a substantial exposure to neurotoxic organic solvents (table 1). In addition, other diseases were excluded as a primary cause to the symptoms and signs of disease. All patients had central nervous symptoms such as memory impairment, concentration difficulties, vertigo, headache, excessive fatigue, depression, and anxiety. Four had symptoms relating to the peripheral nervous system; muscular weakness or parestesias or both (table 2). All patients had a clearly reduced functional intellectual capacity and major deficits in cognitive functioning such as memory and concentration. Some also had impaired sensory motor capacity. Five had diffuse cerebral atrophy and two cerebellar atrophy by a subjective evaluation of an experienced neuroradiologist. Four had an abnormal EEG with increased theta activity over the anterior parts of the brain or over the lateral parts of one or both sides; polyneuropathy was found in four. According to the classification suggested in the United States they had a type $2 b$ syndrome. ${ }^{7}$

One patient refused to undergo a lumbar puncture and two of the specimens of cerebrospinal fluid were lost before the analyses could be performed, leaving

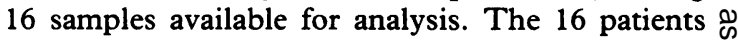
were men aged from 20 to 67 . Their mean exposure to organic solvents was 24 years, ranging from eight to 52 years.

\section{CONTROL GROUP}

The control group consisted of 16 patients examined in our department who had been referred because of $A$ myalgia or backache, or both. They had a normal general and neurological status and further investigations by blood samples, EEG, and computed tomograms of cerebrum and spine did not show any indication of lesion of the nervous system. The 10 women and six men aged between 21 and 68 had had no appreciable exposure to organic solvents. They had a similar socioeconomic and educational level as the patient group.

\section{CEREBROSPINAL FLUID ANALYSIS}

The cerebrospinal fluid $(10 \mathrm{ml})$ was obtained by a standardised procedure. A lumbar puncture was performed with the patient in supine position, before breakfast, after at least eight hours resting. It was stored at $-20^{\circ} \mathrm{C}$ until the analysis was made. Fluid for the analyses was taken from the pooled cerebrospinal fluid volume of $10 \mathrm{ml}$. None of the samples was contaminated by blood. No abnormalities were found in the cerebrospinal fluid as judged by cell count and electrophoresis in either the exposed or the unexposed group. The mean cell value was $2.2 \times 10^{6} / 1$ in the patients (range $0.8-5.3$ ) and $1.9 \times 10^{6} / 1$ in the control group (range $0.4-5 \cdot 0$ ).

Table 2 Age, symptoms, and pathological findings in 16 patients with chronic toxic encephalopathy due to organic solvents

\begin{tabular}{|c|c|c|c|c|c|c|c|c|}
\hline \multirow[b]{2}{*}{$\begin{array}{l}\text { Patient } \\
\text { No }\end{array}$} & \multirow[b]{2}{*}{ Age } & \multicolumn{2}{|c|}{ Symptoms } & \multicolumn{5}{|c|}{ Pathological findings by examination } \\
\hline & & CNS & $P N S$ & $\begin{array}{l}\text { Neurological } \\
\text { examination }\end{array}$ & $\begin{array}{l}\text { Neuro- } \\
\text { graphy }\end{array}$ & $E E G$ & $\begin{array}{l}\text { Cerebral } \\
C T\end{array}$ & $\begin{array}{l}\text { Psychological } \\
\text { testing }\end{array}$ \\
\hline 1 & 67 & + & - & + & - & + & - & + \\
\hline 2 & 66 & + & + & + & + & - & + & + \\
\hline 3 & 65 & + & - & - & - & + & + & + \\
\hline 4 & 64 & + & - & + & - & + & + & + \\
\hline 5 & 63 & + & + & + & + & - & + & + \\
\hline 6 & 63 & + & - & + & - & - & - & + \\
\hline 7 & 58 & + & - & + & - & + & - & + \\
\hline 8 & 55 & + & - & - & - & - & - & + \\
\hline 9 & 50 & + & + & + & + & - & + & + \\
\hline 10 & 48 & + & - & - & - & - & - & + \\
\hline 11 & 45 & + & - & - & - & - & - & + \\
\hline 12 & 37 & + & + & + & + & - & + & + \\
\hline 13 & 35 & + & - & - & - & - & - & + \\
\hline 14 & 35 & + & - & - & - & - & - & + \\
\hline 15 & 33 & + & - & + & - & - & - & + \\
\hline 16 & 29 & + & - & - & - & - & - & + \\
\hline
\end{tabular}


Proteins were separated by agarose gel electrophoresis. Protein concentrations were determined by the folin phenol reagent method. ${ }^{11}$ Concentrations of albumin and immunoglobulin $G$ were measured by a laser nephelometric analysis. Amino acid concentrations were quantitated by high performance liquid chromatography after precolumn derivatisation with o-phthaldialdehyde, as described previously ${ }^{12}$ (and BA Engelsen et al, unpublished data). The concentrations were expressed in $\mu \mathrm{mol} / 1$.

\section{STATISTICAL ANALYSES}

The differences between the two groups regarding concentrations of total protein, albumin, IgG, and amino acids in the cerebrospinal fluid were found by using the Student's $t$ test (two tailed).

The correlations between the measured variables in cerebrospinal fluid, age, and an exposure index were estimated by the use of multiple regression analyses. Age was adjusted by including this variable in all steps of the analyses. The exposure index was estimated for each patient by multiplying the number of years of exposure to solvents with the mean daily exposure time and a factor that rated the degree of exposure from one to four.

\section{Results}

The concentrations of total protein, albumin, and IgG were significantly higher in the patient group compared with the control group (table 3 ).
The IgG/total protein ratio was higher in the patient group (0.108) than in the control group $(0.074)$. The concentrations of phosphoethanolamine, taurine, homocarnosine, ethanolamine, alpha-aminobutyric acid, and leucine were significantly lower in the patient group than in the control group (table 3 ).

In multiple regression analyses of both the patient and reference groups taurine showed a significant negative correlation with increasing solvent exposure $(r=-0.365, p=0.045)$. Most of the other amino acids were negatively correlated with increasing exposure but the correlations were statistically insignificant. Multiple regression analyses were performed analysing the relations to both exposure to organic solvents and age. Age did not interfere with the reported correlations to exposure. Neither age nor exposure showed any correlation to total protein, albumin, or IgG. Multiple regression analyses of the patient group only gave almost identical results as when the two groups were analysed together.

\section{Discussion}

Raised cerebrospinal fluid concentrations of total protein, albumin, and IgG and reduced concentrations of some free amino acids were found in the patients with chronic toxic encephalopathy compared with the control group.

The increased concentrations of protein and

Table 3 Total protein $(\mathrm{g} / \mathrm{l})$, albumin $(\mathrm{g} / \mathrm{l}), \mathrm{IgG}(\mathrm{g} / \mathrm{l})$, and amino acid ( $\mu$ mol/l) concentrations in the cerebrospinal fluid from patients with chronic toxic encephalopathy compared with a reference group

\begin{tabular}{|c|c|c|c|c|c|}
\hline & \multicolumn{2}{|c|}{$\begin{array}{l}\text { Reference group } \\
(n=16)\end{array}$} & \multicolumn{2}{|c|}{$\begin{array}{l}\text { Exposed group } \\
(n=16)\end{array}$} & \multirow[b]{2}{*}{ p Value } \\
\hline & Mean & $S D$ & Mean & $S D$ & \\
\hline $\begin{array}{l}\text { Total protein } \\
\text { Albumin } \\
\text { IgG } \\
\text { Phosphoserine } \\
\text { Aspartic acid } \\
\text { Asparagine } \\
\text { Glutamic acid } \\
\text { Histidine } \\
\text { Serine } \\
\text { Glutamine } \\
\text { Citrulline } \\
\text { Arginine } \\
\text { Threonine/glycine } \\
\text { Phosphoetanolamine } \\
\text { Taurine } \\
\text { Thyrosine/ } \beta \text {-alanine } \\
\text { Homocarnosine } \\
\text { Alanine } \\
\text {;-Amino butyric acid } \\
\text { Ethanolamine } \\
\text { x-Amino butyric acid } \\
\text { Tryptophane } \\
\text { Methionine } \\
\text { Valine } \\
\text { Phenylalanine } \\
\text { Isoleucine } \\
\text { Leucine } \\
\text { Lysine }\end{array}$ & $\begin{array}{c}0.347 \\
0.201 \\
0.026 \\
0.3 \\
1.8 \\
4.4 \\
2.3 \\
6 \cdot 2 \\
22.9 \\
607.7 \\
1.8 \\
24.8 \\
30.0 \\
2.3 \\
8.8 \\
7.8 \\
0.8 \\
27.1 \\
0.3 \\
22.5 \\
3.6 \\
1.8 \\
3.2 \\
15.0 \\
8.2 \\
4.9 \\
14 \cdot 7 \\
39.6\end{array}$ & 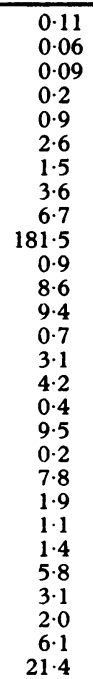 & $\begin{array}{r}0.480 \\
0.301 \\
0.053 \\
0.3 \\
1.6 \\
4.2 \\
2.3 \\
4.1 \\
21 \cdot 1 \\
519.2 \\
1.5 \\
18.8 \\
29.8 \\
1.5 \\
5.1 \\
6.8 \\
0.4 \\
26.9 \\
0.2 \\
12.9 \\
2.4 \\
1.4 \\
2.5 \\
14.8 \\
6.4 \\
3.8 \\
9.8 \\
49.4\end{array}$ & $\begin{array}{r}0 \cdot 17 \\
0 \cdot 13 \\
0 \cdot 05 \\
0 \cdot 2 \\
0 \cdot 7 \\
1 \cdot 8 \\
1 \cdot 3 \\
2 \cdot 5 \\
11 \cdot 8 \\
200 \cdot 1 \\
0 \cdot 8 \\
9 \cdot 1 \\
16 \cdot 1 \\
0 \cdot 7 \\
2 \cdot 0 \\
3 \cdot 2 \\
0 \cdot 2 \\
17 \cdot 1 \\
0 \cdot 1 \\
5 \cdot 5 \\
1 \cdot 3 \\
0 \cdot 5 \\
1 \cdot 3 \\
7 \cdot 9 \\
3 \cdot 2 \\
1 \cdot 6 \\
3 \cdot 7 \\
27 \cdot 9\end{array}$ & $\begin{array}{l}0 \cdot 01 \\
0 \cdot 0057 \\
0 \cdot 0248 \\
\text { NS } \\
\text { NS } \\
\text { NS } \\
\text { NS } \\
\text { NS } \\
\text { NS } \\
\text { NS } \\
\text { NS } \\
\text { NS } \\
\text { NS } \\
0 \cdot 0058 \\
0 \cdot 0002 \\
\text { NS } \\
0 \cdot 0007 \\
\text { NS } \\
\text { NS } \\
0 \cdot 0003 \\
0.0428 \\
\text { NS } \\
\text { NS } \\
\text { NS } \\
\text { NS } \\
\text { NS } \\
0 \cdot 0088 \\
\text { NS }\end{array}$ \\
\hline
\end{tabular}

ॠTwo tailed $t$ test. 
albumin may be due to a protein leak through the blood brain barrier or to reduced cerebrospinal fluid drainage.

The reductions of free amino acid concentrations are difficult to interpret as the functions of the amino acids are still a matter of controversy. Changes in cerebrospinal fluid free amino acid concentrations have been found in some neurological and metabolic disorders ${ }^{13}$ but the clinical relevance of these findings is not known. An additional problem in interpreting the present findings is the methodological differences between the studies. Several studies have been performed to establish normal values of free amino acids in cerebrospinal fluid ${ }^{15}{ }^{15}$ but they are difficult to compare and to use in clinical practice. Because of these differences, a control group was used in the present study.

In our studies the concentration of taurine had a significant negative correlation with exposure to organic solvents. The other amino acid concentrations that were significantly lower in the exposed group compared with the unexposed group showed a similar correlation with exposure but the correlations were not significant. This suggests that the finding is real and not an accidental statistical occurrence due to the high number of analyses performed.

The neurobiological functions of taurine are not yet unequivocally established. Taurine may be a neurotransmitter or function as a neuromodulator..$^{13}$ It has membrane stabilising and inhibitory effects and may be linked to the calcium flow in excitable tissue. ${ }^{91617}$ Taurine may protect cell membranes and cells by attenuating toxic compounds that generate oxidants. ${ }^{18}$ Furthermore, a reduced cerebrospinal fluid taurine concentration has been reported in patients with hereditary mental depression and parkinsonism $^{10}$ and in patients with a reduced level of consciousness. ${ }^{19}$

Acute and chronic exposure to organic solvents may alter membrane fluidity in the central nervous system..$^{20}$ Similar effects occur when the concentration of taurine is reduced. ${ }^{16-18}$ The mechanisms regarding these effects and a possible interaction between taurine and organic solvents are unknown.

Interrelations between levels of extracellular taurine and phosphoetanolamine have been seen in an experimental study and it is suggested that the relation has importance in understanding the effect of taurine on membrane stabilisation and calcium fluxes in excitable tissues..$^{21}$ Another study suggests that ethanolamine may be a product from degradation of membranes. ${ }^{22}$

Amino acid concentrations in the cerebrospinal fluid have not previously been analysed in patients with chronic solvent intoxication syndrome. A few experimental studies of short term solvent exposed rats have been made regarding amino acid concentrations in the rat brain. In the brain of rats exposed to trichloroethylene and tetrachloroethylene no change in taurine concentrations was found. ${ }^{23}$ That study, however, is not exactly comparable with our present study as our patients were exposed to various solvents on a long term basis.

In conclusion, changes in the composition of cerebrospinal fluid may be associated with the diagnosis of chronic toxic encephalopathy. The clinical 0 relevance of these findings are not clear but the amino acid changes may indicate membrane alterations that may be related to the exposure to organic solvents.

Requests for reprints to Bente E Moen, Storetveitvn 184, N-5040 Paradis, Norway.

1 Arlien-Søborg P, Bruhn P, Gyldensted C, Melgaard B. Chronic painter's syndrome. Chronic toxic encephalopathy in house painters. Acta Neurol Scand 1979;60:149-56.

2 Juntunen J, Antti-Poika M, Tola S, Partanen T. Clinical prognosis of patients with diagnosed chronic organic solvent intoxication. Acta Neurol Scand 1982;65:488-503.

3 Axelsen O, Hane M, Hogstedt C. Neuropsykiatriska sjukdom- iA stilstånd hos løsningsmedelsexponerade arbetar-case- is control-studie. Läkartidningen 1976;73:322-5.

4 Ørbaek P, Risberg Z, Rosén, I, et al. Effects of long-term V exposure to solvents in the paint industry. Scand $J$ Work 음 Environ Health 1985;11(suppl 2):1-28.

5 Mikkelsen S, Jørgensen M, Browne E, Gyldensted C. Mixed solvent exposure and organic brain damage. A study of painters. Acta Neurol Scand 1988;78(suppl 118):1-143.

6 World Health Organisation. Chronic effects of organic solvents on the central nervous system and diagnostic criteria. Copenhagen: WHO, 1985. (Environmental health 5.)

7 Cranmer JM, Golberg L. Workshop on neurobehavioral effects of solvents. Neurotoxicology 1986;7:45-56.

8 Wikkelsø C, Ekberg K, Lillienberg L, et al. Cerebrospinal fluid O proteins and cells in men subjected to long-term exposure to organic solvents. Acta Neurol Scand 1984;70(suppl 100): 113-9.

9 Nicoll RA. Physiological studies on amino acids and peptides as prospective transmitters in the CNS. In: Iversen LL, Iversen $\mathbb{D}$ SD, Snyder SH, eds. Psychopharmacology. New York: Plenum Press, 1978:59-89.

10 Perry TL, Bratty PJA, Hansen S, Kennedy J. Hereditary mental depression and parkinsonism with taurine deficiency. Arch Neurol 1975;32:108-13.

11 Lowry OH, Rosebrough NJ, Lewis Farr A, Randall RJ. Protein measurement with the folin phenol reagent. J Biol Chem 1951;193:265-75.

12 Lindroth $\mathbf{P}$, Mopper $\mathrm{K}$. High performance liquid chromatogra- (D) phic determination of subpicomole amounts of amino acids by precolumn fluorescence derivatization with o-phthaldialdehyde. Anal Chem 1979;51:1667-74.

13 Barbeau A, Inoue N, Tsukada Y, Butterworth R. The neuropharmacology of taurine. Life Science 1975;17:669-78. O (Minireview.)

14 Gjessing LR, Gjesdal P, Sjaastad $O$. The free amino acids in $O$ human cerebrospinal fluid. J Neurochem 1972;19:1807-8.

15 Perry TL, Hansen S, Kennedy J. CSF amino acids and plasma - D CSF amino acid ratios in adults. $J$ Neurochem 1975;24:587-9. 으

16 Oja SS, Kontro P. Taurine. In: Lajtha A, ed. Handbook of neurochemistry. Vol 13. Metabolism in the nervous system. 2nd $\mathrm{N}$ ed. New York: Plenum Press, 1983:501-33.

17 Pasantes-Morales $\mathrm{H}$, Arzate NE, Crux C. The role of taurine in $\mathrm{N}$ nervous tissue: its effects on ionic fluxes. In: Huxtable RJ, Pasantes-Morales $\mathrm{H}$, eds. Taurine in nutrition and neurology. N New York: Plenum Press, 1982:273-92.

18 Wright CE, Tallan HH, Lin YY. Taurine; biological update. Ann Rev Biochem 1986;55:427-53.

19 Yanau Y, Shibasaki T, Kohno N, Mitsui T, Nakajima $H$. Concentrations of sulfur-containing free amino acids in lumbar cerebrospinal fluid from patients with consciousness disturbances. Acta Neurol Scand 1983;68:386-93.

20 Finean JB, Coleman R, Michell RH. Membranes and their cellular functions. Oxford: Blackwell, 1984:194-201.

21 Lehmann A, Hamberger A. A possible interrelationship between extracellular taurine and phosphoethanolamine in the hippocampus. J Neurochem 1984;42:1286-90.

23 Perschak H, Wolfensberger M, Do KQ, Dunant Y, Cuenod M. $\sigma$ Release of ethanolamine, but not of serine or choline, in rat pontine nuclei on stimulation of afferents from the cortex, in $\Omega$ vivo. J Neurochem 1986;46:1338-43.

23 Honma T, Hasegawa $H$, Sato $M$, Sudo A. Changes of free amino acid content in rat brain after exposure to trichloroethylene and tetrachloroethylene. Industrial Health 1980;18:1-7. 